\title{
Refractory Histiocytic and Dendritic Cell Neoplasm
}

National Cancer Institute

\section{Source}

National Cancer Institute. Refractory Histiocytic and Dendritic Cell Neoplasm. NCI

Thesaurus. Code C134168.

A histiocytic and dendritic cell neoplasm that does not respond to treatment. 